INNA JERMAKOWA

ORCID: 0000-0003-0867-3982

Katedra Dziennikarstwa,

Doniecki Uniwersytet Narodowy im. Wasyla Stusa w Winnicy

\title{
Wizualizacja jako narzędzie manipulacji współczesnej wojny informacyjno- -hybrydowej. Historia jednej fotografii - „Rozejm w Szyrokinem”
}

\section{Abstrakt}

Dokumentalna natura fotografii przekonuje widza o tym, że to, co na niej widać, odzwierciedla rzeczywistość. Fotografia wzbudza zaufanie, dlatego też nie może dziwić, że ta jej właściwość nieraz była wykorzystywana do sterowania świadomością społeczną. W niniejszej publikacji przeanalizowano środki, przy pomocy których obraz działa na percepcję. Zaakcentowano problem, w jaki sposób samo dziennikarstwo wizualne staje się instrumentem w warunkach wojny informacyjnej podczas konfliktu zbrojnego, w czasach, w których — jak to określiła Oksana Zabużko - „epoka »zbombardowanych miast « przeminęła - zaczęła się epoka »zbombardowanych mózgów«” (Забужко 2016: 12).

Z historii dokumentalistyki fotograficznej i historii ludzkości daje się zauważyć, że wojny czy katastrofy zawsze przyciągały uwagę odbiorców. Fotografia niemal zniwelowała dystans pomiędzy widzem a wydarzeniem. W warunkach rosyjskiej agresji na Ukrainę stała się ona masową i skuteczną bronią w wojnie informacyjnej, wojnie psychologicznej. Znaczenie i prawdziwą skalę owej wojny często bagatelizowano, zakładając, że jest czymś na kształt dodatku do „głównej”, „gorącej” zbrojnej fazy wojny, podczas gdy w rzeczywistości sens jest odwrotny - to właśnie wojna informacyjna jest obecnie totalną, przy czym należy podkreślić, że pierwsze miejsce zajmuje w niej aspekt wizualny.

Materiały fotograficzne i ich pochodne wykorzystywane są skutecznie jako technologie wojny hybrydowej, której skutki mają wpływ również na ukraińską przestrzeń medialną. Do najczęściej używanych środków manipulacyjnych współczesnej wojny informacyjno-hybrydowej zaliczam: przeinaczanie faktów, prowokacje informacyjne, fejki, manipulacje, kolaże fotograficzne, a także mylące sprawozdania naocznych świadków, fałszywych świadków oraz ekspertów.

Słowa kluczowe: fotografia, manipulacja, wojna informacyjna. 
Wojna informacyjna należy obecnie do najbardziej niebezpiecznych broni. W związku z jej rolą we współczesnym świecie teoretyk komunikacji Marshall McLuhan w jednej ze swoich prac stwierdził, że naprawdę totalną jest wojna prowadzona za pośrednictwem informacji (Маклюэн 2007: 91). Zgadzając się z nim, ukraińska pisarka Oksana Zabużko w książce I znowu wsiadam do czołgu pisze:

Nazywają ją „,informacyjną”, „psychologiczną”, „hybrydowąa i jeszcze dziesiątkami proteuszowych pseudonimów - i w ten sposób często gęsto pomniejsza się jej rzeczywisty zakres i znaczenie, gdyż jest ona czymś na kształt dodatku do „głównej”, „gorącej”, podczas gdy w rzeczywistości jest odwrotnie: akurat ona jest główna, całkowita, a „żelazo i krew” - tylko jej pochodną: dodatkiem, który na naszych oczach ciągle redukuje się do atawizmu. Przy obecnym poziomie globalizacji i technologii informacyjnej zdobywać kraje oraz dzielić na nowo zasoby na naszej kulce teoretycznie można, nie doprowadzając agresji do "gorącej” fazy — nie maczając palców we krwi [...]. Krótko mówiąc, epoka „zbombardowanych miast” przeminęła - zaczęła się epoka „zbombardowanych mózgów” [...] ${ }^{1}$. (Забужко 2016: 11-12)

W pracy tej przyjmuję za Gieorgijem Poczepcowem, że „wojna informacyjna” to „technologie informacyjne, które mają wpływ na systemy informatyczne, mające na celu wprowadzenie w błąd świadomość zbiorową lub indywidualną, likwidację lub desynchronizację procesów zarządzania społeczeństwem albo jego częścią, przede wszystkim wojskiem" (Почепцов 2015: 168). Zgadzam się z uwagami wskazanego badacza, że wojny informacyjne nabywają w ostatnich latach różnorodnych cech charakterystycznych, dlatego też określa się je za pomocą rozmaitych terminów. Jednocześnie z dezorientacją, dezinformacją, propagandą i manipulacją mas (zbiorem osób niewyróżniających się niczym szczególnym - I.J.) jako główne narzędzia wojny informacyjnej, jako ataki informacji o informacjach zaczynają być wykorzystywane mechanizmy, które "nie są sprzeczne z faktami, ale ze znaczeniami prowadzącymi do określonych interpretacji faktów” (Почепцов 2016: 5). Obecna wojna to wojna semantyczna (wojna znaczeń), w której „autentyczność faktu [...] nie jest tak istotnym parametrem, jak w przypadku przestrzeni informacji [...]. Fakt jest drugorzędny, pierwszorzędny jest obraz-znaczenie” (Почепцов 2016: 16). W przeciwieństwie do wojny informacyjnej, której celem jest przestrzeń informacyjna, wojna semantyczna wpływa na przestrzeń poznawczą. W związku z tym zmienia przekonania osób, ich świadomość, zakłócając bardziej pogłębione struktury. Wojny informacyjne i semantyczne zarazem stają się narzędziami wojny hybrydowej.

Ekspert polityczny i analityk Jewhen Magda, badający zjawisko współczesnej wojny hybrydowej, zauważa, że

pojawiły się takie pojęcia, jak hybrid warfare czy network centric wafare, którym odpowiada kolejno - wojna hybrydowa oraz wojna centralna w sieci. Terminy te mają na celu zidentyfikowanie nowych zjawisk oraz zjawisk na polach bitewnych XXI wieku. Należy podkreślić, że rozwój podstaw teoretycznych (lub zrozumienia zjawisk) jest wciąż w toku, przynajmniej na Ukrainie. (www5)

${ }^{1}$ Tłumaczenia wszystkich cytatów w tekście - I. Procyk. 
Magda wskazuje, że charakteryzując wojnę hybrydową, należy zwrócić uwagę na: „wykorzystanie broni informacyjnej, udział w opozycji podmiotów niepaństwowych, stosowanie metod terroryzmu, zaniedbanie prawa oraz etyki wojskowej, stosowanie presji ekonomicznej i psychologicznej, propagandę itp." (www5).

Współczesny konflikt zbrojny sprzyja powstaniu dużej liczby różnorodnych informacji, które wytwarzają obie strony biorące udział w wojnie. Do tego zostają zaangażowani nie tylko etatowi propagandyści, lecz także zwykli użytkownicy środków masowego przekazu, korzystający z sieci. Ich uwagę przykuwają zdjęcia oraz filmy, które mają wpływać na ich emocje poprzez podawanie wielu obrazów, na przykład okaleczonych czy martwych ciał, ofiar wśród dzieci i starszych czy zniszczonych domów. Te wstrząsające materiały dokumentacyjne, których użytkownicy są mniej lub bardziej świadomymi odbiorcami, z jednej strony stają się skutecznym narzędziem propagandy i destabilizacji państwa, a z drugiej — wzmagają nienawiść i agresję u osób korzystających z sieci, stanowią uzasadnienie używania przez dany kraj coraz większej i coraz brutalniejszej siły w stosunku do przeciwnika.

Celem artykułu jest pokazanie, jak manipuluje się fotografią oraz w jaki sposób sam obraz może stać się potężnym narzędziem dezinformacji w warunkach wojny informacyjno-hybrydowej, która toczy się na wschodzie Ukrainy.

W wojnie informacyjno-hybrydowej, która toczy się na wschodniej Ukrainie, często wypacza się fakty, stosuje prowokacje poprzez podawanie nieprawdziwych informacji, wykorzystując jako narzędzie manipulacji między innymi fotoreportaże, kolaże zdjęć, filmy, zdjęcia czy fejki (to znaczy różne informacje, filmy, zdjęcia, kolaże, zamieszczane w Internecie, które zawierają jakiś sfałszowany element). Do nakłaniania do swoich racji służy między innymi także powoływanie się na opinię publiczną, opinie (zdania) ekspertów oraz komentarze naocznych świadków, bardzo często przy wykorzystaniu zdjęć przedstawiających jakieś wydarzenie, niekoniecznie związane $\mathrm{z}$ daną sprawą. Jednym $\mathrm{z}$ takich przykładów może być używanie przez rosyjskie portale internetowe materiałów fotograficznych z wojny w Gruzji, Syrii lub w tej samej Rosji (na przykład z wojny czeczeńskiej) (www7) jako ilustracji rosyjsko-ukraińskiego konfliktu na wschodzie Ukrainy, mających potwierdzać rzekome zbrodnie wojenne popełniane przez ukraińskie siły zbrojne na cywilach. Przy zastosowaniu manipulacji oraz propagandy chce się wywrzeć wpływ na użytkowników mediów społecznościowych: wzbudzić negatywne emocje, takie jak gniew, lęk, złość, nienawiść itp., co w konsekwencji może prowadzi do utraty umiejętności odczytywania fałszywych argumentów i niezdolności samodzielnego, krytycznego myślenia.

Obecnie mass media odgrywają na Ukrainie bardzo dużą rolę. Te tradycyjne telewizja, radio czy gazety - coraz częściej muszą konkurować z mediami internetowymi. Zjawisko to będzie się nasilać, ponieważ - jak zauważył Roman Kabaczij, przedstawiciel Instytutu Informacji Masowej, w swoim wystąpieniu w 2016 roku w ramach Media Obozu „Narzędzia wpływów” - w krajach o niskim poziomie zaufania do klasycznych mediów (w tym na Ukrainie) bardziej wiarygodne i po- 
pularne stają się alternatywne źródła informacji, na przykład Facebook. Użytkownicy aktywnie korzystają z niego nie tylko do prywatnych kontaktów, lecz także między innymi w celu uzyskania informacji (www4). Niesie to z sobą zagrożenie bezkrytycznego przyjmowania wiadomości z różnych źródeł, zwłaszcza przez osoby niewykształcone oraz nieumiejące weryfikować informacji podawanych w sieci. W 2016 roku w porównaniu z 2014 wzrosła liczba działań na rzecz poprawy edukacji medialnej (por. prace m.in. G. Onkowycz, A. Fedorowa). Bardzo pożyteczne okazały się portale internetowe prowadzone przez dziennikarzy w celu zdemaskowania fałszywej, prowokacyjnej informacji wizualnej.

Ponad 60\% informacji odbieramy za pomocą wzroku, dlatego nie może dziwić, że wszelkie elementy graficzne, zdjęcia dokumentalne, fotoreportaże itp. są obecnie obowiązkowym elementem każdego wydania informacyjnych serwisów internetowych, zwłaszcza dotyczących wojny. Historia światowej fotografii dokumentalnej, która na dobre zaczęła się rozwijać od pokazania wojny krymskiej z 1855 roku oraz jej skutków, zdaje się potwierdzać, że obrazy nieszczęść: wojny, konfliktów zbrojnych, katastrof przyciągały i przyciągają więcej uwagi niż tekst ${ }^{2}$. Zdjęcie skraca dystans między odbiorcą-widzem a wydarzeniem. Przedstawia je w sposób bardziej zwięzły, a w niektórych wypadkach bardziej wyrazisty niż tekst, który je opisuje. Często biorąc do ręki gazetę lub otwierając stronę internetową, odbiorca skupia się na obrazie (obrazach); jeżeli nawet słyszał o czymś, ale nie widział tego na fotografii, może mieć wątpliwości, czy taka sytuacja miała miejsce. Fotografia ma być gwarancją prawdziwości wydarzenia. W wojnie informacyjno-hybrydowej toczącej się obecnie na wschodzie Ukrainy ta sytuacja uległa zmianie. Eskalacji agresji militarnej towarzyszy intensyfikacja działań dezinformacyjnych. Niektórzy dziennikarze oraz propagandyści, sięgając po nowe technologie medialne, wykorzystują między innymi fotokolaże, fotografie inscenizowane, czyli takie, które przedstawiają rzeczywisty obraz, ale skonstruowany na potrzeby konkretnego zdjęcia, a także fotografie manipulowane, czyli powstające w wyniku rejestracji oraz interpretacji fotograficznej w już zarejestrowanym obrazie. Niejednokrotnie łączą złe praktyki zawodowe z brakiem profesjonalizmu, ignorancją lub przekraczaniem zasad etyki dziennikarskiej.

Jednym z takich jaskrawych przykładów naruszenia podstawowych zasad etyki był album fotografii zatytułowany Ból wojny, autorstwa fotografa Dmytra Murawskiego $^{3}$, o rosyjsko-ukraińskim konflikcie zbrojnym, opublikowany przez niego 16 sierpnia 2016 roku na Facebooku (www3, por. www9). Szczególnie dużą popularnością cieszyło się zdjęcie przedstawiające moment wybuchu i ucieczkę trzech

${ }^{2}$ Autorem zdjęć dokumentujących wojnę krymską (1854-1855) jest prawnik Roder Fenton. Jego fotografie ze względu na wiktoriańską moralność nie przedstawiały jednak okropieństwa wojny. Obecnie są przykładem zobrazowania konfliktu zbrojnego bez pokazywania przemocy (www1).

${ }^{3}$ Dmytr Murawski był kierownikiem Centrum Koordynacji i Informacji w Urzędzie Komunikacji i Prasy Ministerstwa Obrony Ukrainy. Został powołany na to stanowisko przez ministra Stepana Połtoraka już w trakcie prac mających na celu publikację zdjęć. 
żołnierzy tuż po ataku na wioskę Szyrokine koło Mariupola. Tę samą fotografię już w ten sam dzień opublikował na swojej stronie na Facebooku redaktor naczelny wydania internetowego cenzor.net.ua - Jurij Butusow, zachęcając do jej rozpropagowania w sieci i do przesyłania jej na konkursy fotograficzne, aby o wydarzeniach w Mariupolu dowiedział się cały świat. Redaktor dodał, że zdjęcie zostało zrobione w miejscowości Szyrokine 4 czerwca 2016 roku (www2). Następnego dnia zliczono, że zdjęcie rozpowszechniono w Internecie ponad sześć tysięcy razy. Zostało też umieszczone $\mathrm{w}$ gazecie „Business Insider” $\mathrm{z}$ dopiskiem „Obrazy $\mathrm{z}$ frontu ukraińskiego konfliktu - żywe przypomnienia o wojnie, która trwa w Europie”. Ponadto szwedzki polityk Carl Bildt zamieścił je na swoim Twitterze. Użytkownicy portali społecznościowych określili tę fotografię najlepszym przykładem fotoreportażu z linii frontu oraz dowodem naruszenia rozejmu przez wojskowe grupy separatystyczne w Donbasie (www2). Wykorzystywano ją także jako materiał dokumentalny do walki w strefie ATO (strefie operacji antyterrorystycznej) (www5). Niektórzy użytkownicy Facebooka oraz przedstawiciele ukraińskich mediów, w tym wielu fotoreporterów, miało wątpliwości co do prawdziwości tego „skądinąd bardzo dobrego zdjęcia”4. Pojawił się szereg pytań: „czy to autentyczny obraz?”, „czy nie jest inscenizowany?”, „czy nie jest to kolaż?”, „czy nie zastosowano manipulacji w już zarejestrowanym obrazie?". Podejrzewano, że może jest to fałszywe zdjęcie prawdziwych wydarzeń, których celem było wzmocnienie przekazu ze strefy ATO.

Ukraińscy fotografowie zareagowali natychmiast po opublikowaniu zdjęcia przez Murawskiego. Uznali, że doszło do złamania zasad etyki dziennikarskiej przez autora. Wskazali, że ewentualne oszustwo może zaszkodzić wizerunkowi Ukrainy na arenie międzynarodowej. Wydali w tej sprawie list otwarty zatytułowany „Oświadczenie ukraińskich fotoreporterów co do sytuacji ze zdjęciami Dmytra Murawskiego", w którym napisali:

Podkreślamy, że na razie wygrywamy konflikt z Rosją tylko w bezkompromisowym i prawdziwym przedstawieniu informacji ze strefy walki. Biorąc pod uwagę, że w sieci oraz w zagranicznych mediach krąży - naszym zdaniem - dezinformacja na temat autentyczności obrazów w fotografiach Dmytra Murawskiego, zdecydowanie potępiamy taką manipulację zdjęciami oraz informacją. (www5)

Po głośnych sporach autor zdjęcia przyznał, że zostało ono uprzednio przygotowane i zainscenizowane. Zdjęcia Dmytra Murawskiego zdążyły już jednak zaszkodzić reputacji ukraińskiego dziennikarstwa. Dziennik „The Washington Post” napisał o sfałszowaniu fotografii; eksperci kalifornijskiego Center for Nonproliferation Studies (Centrum Badań nad Nierozprzestrzenianiem Broni) stwierdzili, że zdjęcie zostało zrobione 4 czerwca o godzinie 12:50; a rzeczniczka Organizacji Bezpieczeństwa i Współpracy w Europie (OBWE) Alexandra Taylor złożyła oświadczenie:

4 Takie określenie pojawiało się wśród dziennikarzy komentujących samo zdjęcie i postawę jego autora (www5). 
Kijów twierdzi, że wtedy wieś doznała „wrogiego ataku” i ostrzału, jednak OBWE, jaka była w ten dzień [4 czerwca, od godz. 9:00-11:00 - I.J.], we wsi, żadnych wybuchów nie odnotowała. (www6)

Ponadto Wiktor Moroz — plutonowy jednego z ukraińskich batalionów wojskowych, które znajdowały się w tym czasie w Szyrokinem — oświadczył, że zdjęcie było inscenizowane, ponieważ żadnego ostrzału we wsi w tym czasie nie było.

Zamieszanie wokół omawianej fotografii ujawniło także jeden z problemów społecznych ukraińskiego społeczeństwa. Wiele osób stanęło bowiem w obronie Dmytra Murawskiego, argumentując, że kraj, który jest w stanie konfliktu zbrojnego, powinien „analogicznie odpowiadać na informacyjną agresję" oraz że w warunkach wojny fakt dokumentalności, autentyczności zdjęcia nie jest priorytetowy; najważniejsze są treść obrazu i przekaz, jaki z sobą niesie.

Taką społeczną reakcję próbował wytłumaczyć Wiktor Myronenko - historyk fotografii, pracownik naukowy Kijowskiego Uniwersytetu Technologii i Wzornictwa - wyjaśniając percepcję fotografii wojennej we współczesnym społeczeństwie ukraińskim:

Postrzeganie śmierci na fotografii jest skomplikowane dla nas (ludzi postsowieckich) poprzez wizualną niewiedzę. Powodem takiej niewiedzy jest ideologiczny i propagandowy charakter obrazów fotograficznych wojny (II wojny światowej), do wykorzystywania których został przyzwyczajony postsowiecki widz. Postrzeganie śmierci, percepcja fotografii bez ideologicznego obciążenia dla takiego widza jest prawdziwym wyzwaniem, w przeciwieństwie do zachodnich widzów, którzy przyzwyczajeni są do innych zdjęć, gdzie prawdziwy, dokumentalny obraz był najważniejszy ${ }^{5}$.

Podczas konfliktów zbrojnych wszelkie dziedziny działalności ludzkiej, zwłaszcza nowe technologie (high-tech), stają się aktywnym narzędziem konfrontacji. $\mathrm{W}$ pierwszym jej etapie niszczące skutki, jakie z sobą niesie, mogą być mniej widoczne, gdyż nie prowadzą bezpośrednio do rozlewu krwi i ofiar, nie zawsze są też łatwo rozpoznawalne. W dłuższej perspektywie wojna informacyjno-hybrydowa jest wyniszczająca, między innymi zakłóca równowagę psychiczną, zwiększa emocjonalność percepcji, bezkrytyczne przyjmowanie podanej informacji. Jej konsekwencje mogą okazać się nie mniej katastrofalne niż walka prowadzona przy użyciu tradycyjnej broni. Spustoszenie, jakie wywołuje w psychice społeczeństwa, może okazać się długotrwałe i porównywalne ze skutkami walki zbrojnej, ponieważ, jak zauważyła Oksana Zabużko,

taki oto „agregatowy stan mózgów” [...] najwyraźniej będzie ostatecznym celem wojen 21 wieku: fizycznie żyjesz, ale w rzeczywistości jesteś już zabity — zmysły przestały dostarczać wystarczających informacji o świecie zewnętrznym. (Забужко 2016: 19)

${ }^{5}$ Cytat pochodzi z wywiadu, który przeprowadziłam w trakcie zbierania materiałów do tego artykułu. Cały wywiad znajduje się w zbiorach autorki. 


\section{Bibliografia}

Забужко О. (2016): І знов я влізаю в танк... Вибрані тексти 2012-2016: Статті, есе, інтерв'ю, спогади, Київ.

Маклюэн М. (2013): Галактика Гутенберга. Становление человека печатающего, Москва.

Маклюэн М. (2007): Понимание медиа: внешние расширения человека, Москва.

Почепцов Г. (2015): Сучасні інформаційні війни, Київ.

Почепцов Г. (2016): Смисли і війни: Украӥна і Росія в інформаційній і смисловій війнах, Київ.

Расторгуєв С.П. (2008): Інформаційна війна, Москва.

Рижков М. (2011): Інформаційна війна. Політична енциклопедія. red. Ю. Левенець et al., Київ.

Федоров А.В., Левицкая А.А., Челышева И.В., Мурюкина Е.В., Григорова Д.Е. (2014): Медиаобразование в странах Восточной Европы www.ifap.ru/library/book544.pdf (dostęp: 17.03.2017).

\section{Źródła internetowe}

www1: http://adrianwykrota.fotoblogia.pl/122,co-z-ta-fotografia-dokumentalna-dokument-fotograficzny-na-swiecie-cz-1 (dostęp: 4.07.2017).

www2: http://facebook.com/butusov.yuriy/posts/1305122182861408 (dostęp: 16.08.2016).

www3: http://facebook.com/photo.php?fbid=1058326250909922\&set=a.1058326150909932.1073741

849.100001976712198\&type=3\&theater (dostęp: 16.08.2016).

www4: http://izolyatsia.org/ru/project/instruments-of-influence (dostęp: 30.10.2016).

www5: http://journals.iir.kiev.ua/index.php/pol_n/article/view/2489 (dostęp: 16.08.2017).

www6: https://pl.sputniknews.com/swiatowa_prasa/201608283781185-ukraina-donbas-konflikt-fotogra-

fie (dostęp: 4.07.2017).

www7: http://stopfake.org (dostęp: 19.06.2014).

www8: http://ukr.lb.ua/blog/lbua/ 343305_zayava_ukrainskih_fotozhurnalistiv.html (dostęp: 22.08.2016).

www9: http://wschodnik.pl/ukraina/item/7532-w-wyniku-skandalu-fotograf-ato-zwolniony-przez-ukrainski-mon.html (dostęp: 4.07.2017).

www10: http://www.irbis-nbuv.gov.ua/cgi-bin/irbis_nbuv/cgiirbis_64.exe?I21DBN=LINK\&P21DBN=

$\mathrm{UJRN} \& Z 21 \mathrm{ID}=\& \mathrm{~S} 21 \mathrm{REF}=10 \& \mathrm{~S} 21 \mathrm{CNR}=20 \& \mathrm{~S} 21 \mathrm{STN}=1 \& \mathrm{~S} 21 \mathrm{FMT}=\mathrm{ASP} \_$meta\&C21COM=S\&2_

S21P03=FILA=\&2_S21STR=Grani_2015_3_5 (dostęp: 16.08.2017).

\section{Visualization as a tool for manipulating the modern information-hybrid war. History of one photo - "The truism in Szyrokine"}

\section{Summary}

Documentary nature of photography convinces the viewer that the image is exactly the same as reality. A photo causes trust and this property of photos is repeatedly used in manipulating public opinion. In the report perception means of the image are analyzed. Special attention is paid to the fact how photojournalism becomes the powerful tool in terms of information war against a backdrop of military conflicts. Especially in today's conditions, when, according to Oksana Zabuzhko: "Era of »bombed cities« passed — the era of »bombed brains« began...". 
History of photodocumentary and history in general can argue that wars and disasters always attracted the attention of the news. A photo neutralized the distance between the viewer and the event. But at the same time, in terms of Russian aggression against Ukraine, it became a popular and effective weapon in the "information" or "psychological war". The meaning and the true scale of this war are often underestimated. It is perceived like a sort of supplement to "main", "hot" armed phase of the war. But in reality the meaning is reversed: the information war is total. Moreover, the visual aspect of it is paid the main attention.

Photos and their variations are successfully used as a technology of hybrid war. The consequences of this are so powerfully felt by Ukrainian media space. To the most used means we include misrepresentations, information provokes, fakes, manipulations, photo collages, false testimonies of witness, fake experts and witnesses and others. These technologies are analyzed in the report as manipulative tools of modern information and hybrid war.

Keywords: photo, manipulations, information warfare. 